\title{
Transforming Nigerian Youth Leadership Capacities in Secondary Schools through Principals' Managerial Role Effectiveness
}

\author{
Aniefiok Oswald Edet ${ }^{1,{ }^{*}}$, Uduak Imo Ekpoh ${ }^{1} \&$ Esther Samuel Uko ${ }^{1}$ \\ ${ }^{1}$ Department of Educational Administration \& Planning, University of Calabar, Calabar, Cross River State, Nigeria \\ *Correspondence: Department of Educational Administration \& Planning, University of Calabar, Calabar, Cross \\ River State, Nigeria. Tel: 234-803-724-7488. E-mail: draniefiokedet@yahoo.com
}

Received: July 13, 2015

doi:10.5430/wje.v5n5p77
Accepted: August 15, $2015 \quad$ Online Published: October 7, 2015

URL: http://dx.doi.org/10.5430/wje.v5n5p77

\begin{abstract}
The study examined principals' management role effectiveness of secondary schools for youth leadership in Calabar Education Zone of Cross River State. The study employed survey research design. The target population comprised all 158 principals in both public and private secondary schools in the study area. The sample selected through random sampling technique consisted of 35 public and 35 private secondary schools principals, bringing it to a total of 70. Three research hypotheses were formulated to guide the study. Data were collected through questionnaire titled: Principals Management Role Effectiveness Questionnaire (PMREQ). They were tested at 0.05 level of significance using independent t-test and Pearson Product Moment Correlation Coefficient statistical technique. Result obtained indicated that there was no significant difference between the male and female principals as well as public and private schools principals in their role effectiveness for youth leadership. Hypothesis three revealed a significant relationship between principal's administrative competence and the development of effective leadership role among secondary school students in Calabar Education Zone of Cross River State. The study concluded that principals' management role effectiveness could be a veritable tool for transforming youth leadership capacities. It therefore suggested that induction courses for principals on management strategies should be organized regularly. Furthermore, funding of institutions should be practicalized to ease managerial stress from principals.
\end{abstract}

Keywords: principals; role effectiveness; management; youth leadership

\section{Introduction}

The effectiveness of secondary school principals' role for youth development and leadership is a critical issue to be considered in any discourse on national development. The youth comprise a considerable percentage of Nigeria's population. Their actions or inactions as leaders of tomorrow would most likely have impact on the development of the nation (Enueme \& Atokolo, 2008). Education therefore is the appropriate tool that can help facilitate the elimination of ignorance, illiteracy, disease and poverty among them. This is confirmed in the Transformation Agenda (2011-2015) which describes education as being concerned with the development of "the whole person," including intellectual, character and psychomotor. It is for this reason that it occupies an important place in most plans for economic and social development. Moreover, it opens up opportunities for both individual and group empowerment. Education is particularly important in human development as a supplier of trained manpower which is a prerequisite for the accomplishment of other development goals. It is a vital tool for transformation and the key to the sustainable development of a nation. Education is the most crucial instrument for empowering young people with knowledge and skills which in turn provide them access to productive employment. Also, in Nigeria's Philosophy of Education, Federal Republic of Nigeria (FRN, 2008: 2) it has already been stated that:

(a) Education fosters the worth and development of the individual, for the individual's sake, and for the general development of the society

(b) There is need for functional education for the promotion of a progressive, united Nigeria; to this end, school programmes need to be relevant, practical and comprehensive; while interest and ability should determine an individual's direction in education. 
Interest and ability which determine individual's direction can only be identified in the individual at the secondary school level of education. This level of education is received after primary and before tertiary stage. Secondary school education is therefore critical because it is at this level of education that potentials, skills, abilities are identified, empowered and directed towards the choice of a life-time career and leadership. The need for quality education at this level has been receiving more attention now than ever before and the principal (administrator) has been identified as a key actor in the education process.

According to Ezenwanne (2009), the principal is essentially an organizer and implementer of plans, policies and programmes meant for secondary education. His leadership tasks include: planning, decision-making, coordinating, organizing and directing the facilities, teachers and student in an environment conducive to the maximum development of the learners as future leaders. Ayeni (2012) sees principalship as a well established position of the chief executive who provides instructional leadership by coordinating curricula, co-curriculum programmes and is responsible for the general administration of the secondary school. They are at the vantage positions to supervise, monitor, assess, evaluate and disseminate current information on educational issues and modern teaching techniques to teachers in order to stimulate them for scholarship and best practices in curriculum delivery.

Managing education for youth leadership can be achieved in schools through the principal's effective supervision of all school programmes especially coordinating instructional process. Effective school principals often establish clearly defined goals for academic achievement, and they concentrate their available resources and their operations on attaining them, through such actions as: provide adequate time-table for teaching, routine check of lessons notes and subject dairies, reinforcement of students for excellent performance, maintenance and appropriate usage of physical facilities, enforcement of discipline to ensure peaceful atmosphere, capacity building of teachers for effective service delivery and provision of instructional facilities and materials to enhance quality teaching-learning process (Ayeni, 2012).

Other supervisory task of the principal according to Harris (1967) include developing curriculum guides, instituting new courses (subjects), orienting staff members, developing public relations, assuring the availability of instructional staff members in adequate numbers with appropriate competencies for facilitating instructions, implementing procedures for data gathering analysis and interpretation and decision-making for improvement of instruction. Udoh and Akpa (2007) submitted that the principal's main tasks also include: interpreting policies, executing instructional programmes, maintaining strong liaison with ministry of education, educational statutory agencies and other organizations which may have influence on the school programmes.

However, it should be noted that the various task listed above are not mutually exclusive. The complexity of the relationships between various tasks demands the application of systems analysis in order to improve the understanding both of the task component that form the educational system and of their interaction with one another. To accomplish these tasks and manage the complexity of problems generated by fast growing Nigeria's educational system, as in most other developed countries, the principal must have knowledge of the psychology of human learning, have a command of the various theories of management and instructions, be acquainted with the sources and uses of instructional media/materials, be familiar with evaluation techniques, be skilled in individual and group counseling and have a good knowledge of the Nigerian education system and goals (Lucio \& McNeil 1979; Adetula, 2005). To achieve these educational goals and objectives, the school principals must be familiar with educational laws, roles and regulations, as well as, system polices and management techniques. Some of these techniques include: Forecasting Technique, Analytical Models, Decision Matrix, Decision Tree, Time Tabling and Budgeting (Udoh \& Akpa, 2007).

Forecasting technique according to Udoh and Akpa, (2007) provides an important input into the decision making process that aims at improving results. Principal's interest in the future stems from the fact that they have to make decisions today about the uncertain tomorrow. An educational manager (Principal) has to be clear about the purpose and scope of a forecast. He should be able to classify factors that influence a forecast into indigenous (within the decision makers control) or exogenous (outside the decision makers control). They must also be sure of the quality of data and relevance to the problem under consideration. Some of the forecasting tools relevant to educational decision making are "Eye Balling", Compound Growth Rate, Trend Exploration, Moving Average, Regression Analysis and Morphological Research. The application of analytical models implies a systematic attack on complex problems in an effort to seek opinions or satisfactory solutions. Analytical models include forecasting models, linear programming, and so on. The benefits of the application of analytical models to educational problems include: an explicit thinking about goals and constraints and alternative courses of actions. 
Simulation is a process conducted either by person and/or devices by which a model is made to imitate reality. The aim is not to recreate reality but attract the most important aspects and relationships from reality and express them in a form suitable for analysis. Such model can be used to determine the degree to which outcomes are sensitive to variations in the values of uncertain parameters. The results permit the educational administrators to judge the sensitivity of their plans to such variations. Decision Matrix is one of the latest management tools developed by George L. Morrissey in 1975 (Udoh \& Akpa, 2007). This technique helps in setting priority order for choosing which existing programmes should be expanded or what new programmes should be added.

Decision Tree technique is that of constructing a decision tree which is very useful where series of decisions are to be taken. It facilitates a manager to arrive at prompt and sound decision. It also helps the decision maker to make a systematic presentation either in defence or explanation of any decision or clarification of relevant aspects to enable the decision-maker to arrive at a sound decision. From the above discussion, Principals play an essential role as school leaders to achieve educational goals and objective. They are the guiding force which makes schools what they should be. The effectiveness in carrying out these roles determine the type of graduates that are turned out yearly into the society to take up leadership roles or responsibility.

The contribution of schools to youth empowerment for leadership certainly depends on the motivations and capacities of principals and teachers acting both individually and collectively. Ezekiel-Hart (2009) stated that there is a renewed attention on education as a result of several larger trends and conditions. According to her, the outcomes of schooling are coming under greater scrutiny as most school leavers cannot defend their certificates, talk less of fitting into leadership positions. Educational leadership in schools is assumed to be largely affected by the larger social, political and economic environment surrounding schools, thus raising complex and new challenges for educational leaders. Bass and Stog (1990) and Yuks (1994) hold the view that leadership matters and the changing needs of educational systems can be met, at least in part, by improving leadership capacity and practice. It is against this background that this study seeks to determine the management roles effectiveness of secondary school principals for youth leadership and national transformation.

\section{Statement of the Problem}

The principal holds a key management and supervisory position in secondary school administration that could transform Nigerian youths in terms of leadership capacities. The performances of the evolving complex roles of these principals have sometimes met with stiff challenges that have created gaps in the learning-teaching process. One of such challenges facing secondary school management is the tremendous expansion of education in Nigeria since independence. Regrettably, this expansion has not yet been matched with corresponding management facilities for effective teaching and learning. It has also been widely speculated that the rising cases of declining teacher morale and attrition, coupled with low academic achievement of students might be due to management and supervision inefficiencies. The persistence of such problems in schools reduces the prospect of success of youth empowerment for leadership and subsequent national transformation. The present study therefore is to examine principals' management role effectiveness of secondary schools for youth leadership in Calabar education zone of Cross River State.

\section{Purpose of the Study}

The purpose of this study includes:

1) To determine the difference in role performance effectiveness of male and female principals in the management of secondary school for youth leadership.

2) To find out the difference in management role performance effectiveness for youth leadership of public and private secondary school principals

3) To determine the influence of principals' management role effectiveness on youth leadership in secondary schools.

\section{Hypotheses}

$\mathbf{H}_{01}$ : There is no significant difference between male and female principals management role dissemination in the management of secondary schools in Calabar Education Zone of Cross River State, Nigeria.

$\mathbf{H}_{\mathbf{0 2}}$ : There is no significant difference in secondary school principals managerial competences between public and 
private secondary schools in Calabar Education Zone of Cross River state, Nigeria.

$\mathbf{H}_{03}$ : Principal's administrative competence has no significant relationship with the development of effective leadership role among secondary school students in Calabar Education Zone of Cross River State, Nigeria.

\section{Methodology}

The study employed survey research design in the area under study that is, the Calabar Educational Zone of Cross River State that comprises seven (7) Local Government Areas. The study population covered all 70 public and 88 private secondary schools, bringing it to a total of 158 principals and 2008 teachers. Random sampling technique was adopted to select 70 principals while stratified random sampling was adopted to select 280 teachers. The sample size was 70 principals ( 35 from each school type) and 280 teachers. The teachers were used to assess the principals' management role effectiveness for youth leadership.

A four point Likert type scale questionnaire was the instrument used for data collection. The instrument contained two parts, A and B. Part A elicited personal data while part B contained 24 structured items. The items were on a scale of very effective $=4$ points, somewhat effective $=3$ points, very ineffective $=2$ points and somewhat ineffective $=1$ point.

The validity of the instrument was established by two experts in Educational Foundation and Measurement/Evaluation in terms of content and face validity. The reliability of the instrument was determined using 20 principals and 80 teachers in another area who were not involved in the study. Cronbach Alpha formula was used to compute the reliability coefficient of the instrument. A coefficient of ' $r$ '- -0.70 was obtained. Two hundred and eighty questionnaires were administered on 280 teachers who assessed principals' management role effectiveness. All the questionnaires were retrieved and used for computation. Two hypotheses were analyzed using independent t-test analysis while the third hypothesis was analyzed using Pearson Product Moment Correlation Coefficient.

\section{Findings and Results}

\section{Hypothesis 1}

There is no significant difference between male and female principals in their management role effectiveness for youth leadership.

The independent variable in this hypothesis is gender, categorized into male and female, while the dependent variable is management role effectiveness for youth leadership. Independent t-test statistical technique was used to compare the mean score from the two groups. Summaries of the results are presented in Table 1.

Table 1. Independent t-test Statistical Analysis of the Difference between Male and Female Principals in Their Management Effectiveness for Youth Leadership

\begin{tabular}{lccccc}
\hline Variables & \multicolumn{3}{c}{ Male $(\mathrm{N}=35)$} & \multicolumn{2}{c}{ Female $(\mathrm{N}=35)$} \\
\cline { 2 - 6 } & $\overline{\mathrm{x}}$ & $\mathrm{SD}$ & $\overline{\mathrm{x}}$ & $\mathrm{SD}$ & $\mathrm{t}$ \\
\hline Curriculum development & 11.89 & 1.92 & 11.71 & 2.33 & 0.336 \\
In-service education for staff & 11.34 & 2.11 & 10.91 & 2.38 & 0.796 \\
Development of leadership skills & 11.37 & 2.10 & 12.11 & 1.64 & -1.648 \\
Staff motivation & 11.17 & 1.65 & 11.80 & 1.78 & -1.531 \\
Maintenance of existing facilities & 11.51 & 2.24 & 12.00 & 1.61 & -1.042 \\
Monitoring of school activities & 12.60 & 2.30 & 12.69 & 2.14 & -0.161 \\
\hline
\end{tabular}

Not significant at $0.05 ; \mathrm{df}=68$; critical $\mathrm{t}$-value $=1.994$

Results presented in Table 1 reveal that the calculated t-value was less than the critical t-value of 1.994 at 0.05 level of significance and 68 degrees of freedom. With this result, the null hypothesis was accepted, while the alternate hypothesis was rejected. This means that there is no significant difference between male and female principals in their management role effectiveness for youth leadership.

A further look at the results revealed that male principals had higher mean values in two (2) management role effectiveness for youth leadership, while their female counterparts had higher mean values in four (4) management role effectiveness for youth leadership. This, by implication showed that female principals performed better in their 
management role effectiveness for youth leadership. However, the difference was not high enough to produce a significant difference.

\section{Hypothesis 2}

There is no significant difference between public and private secondary school principals in their management role effectiveness for youth leadership. The independent variable is type of school categorized into public and private while the dependent variable is management role effectiveness for youth leadership. Independent t-test statistical analysis was used to compare the mean scores from the two categories of principals.

Table 2. Independent t-test Statistical Analysis of the Difference between Public and Private Secondary School Principals in Their Management Role Effectiveness for Youth Leadership

\begin{tabular}{lccccc}
\hline \multirow{2}{*}{ Variables } & \multicolumn{2}{l}{ Public $(\mathrm{N}=35)$} & \multicolumn{2}{c}{ Private $(\mathrm{N}=35)$} & $\mathrm{t}$ \\
\cline { 2 - 6 } & $\overline{\mathrm{x}}$ & $\mathrm{SD}$ & $\overline{\mathrm{x}}$ & $\mathrm{SD}$ & \\
\hline Curriculum development & 11.63 & 2.31 & 11.97 & 1.93 & -0.673 \\
In-service education for staff & 11.00 & 2.54 & 11.26 & 1.93 & -0.476 \\
Development of leadership Skills & 12.03 & 1.69 & 11.46 & 2.09 & 1.258 \\
Staff motivation & 11.71 & 1.79 & 11.26 & 1.67 & 1.105 \\
Maintenance of existing Facilities & 12.00 & 1.86 & 11.51 & 2.03 & 1.042 \\
Monitoring of school activities & 12.57 & 2.08 & 12.71 & 2.36 & -0.269 \\
Not significant at 0.05; df =68; critical t-value $=1.994$ & & & \\
\hline
\end{tabular}

Results presented in Table 2 showed that the calculated t-value was found to be less than the critical t-value of 1.944 at 0.05 level of significance and 68 degrees of freedom. Thus, the null hypothesis was accepted while the alternate hypothesis was rejected. This means that there is no significant difference between public and private secondary school principals in their management role effectiveness for youth leadership. Further observation of the result showed that public secondary school principals had higher mean values in three management role effectiveness for youth leadership than their private secondary school principal counterparts. The same is applicable to private secondary school principals who were found to have higher mean values in three management role effectiveness for youth leadership. However, these differences were minimal to produce any significant difference.

\section{Hypothesis 3}

Principals' administrative competence has no significant relationship with development of effective leadership role among secondary school students in Calabar education zone of Cross River State.

The dependent variable of this hypothesis is principal's administrative competence. While the independent variable of the study is development of effective leadership role in terms of curriculum development, in-service education for staff, development of leadership skills, staff motivation, maintenance of existing facilities, and monitoring of school activities.

Four teachers' were selected to assess each principal's administrative competence and development of effective leadership role. Scores obtained from their individual assessments were sum and the average were used to represent principals' administrative competence and development of effective leadership role among secondary school students in Calabar Education Zone with regards to each of the sub-variable. Data collected were coded accordingly and analyzed using Pearson Product Moment Correlation Coefficient Analysis test statistic. Summary of the results are presented in Table 1 below; 
Table 3. Summary of Pearson Product Moment Correlation Coefficient Analysis of the Relationship between Principals' Administrative Competence and Development of Effective Leadership Role

\begin{tabular}{lllll}
\multicolumn{1}{c}{$\mathrm{N}=70$} & & & \\
\hline Variables & $\sum \mathrm{x}$ & $\sum \mathrm{x}^{2}$ & & \\
& $\sum \mathrm{y}$ & $\sum \mathrm{y}^{2}$ & $\sum \mathrm{xy}$ & $\mathrm{r}$. \\
\hline Principal Administrative & 940 & 12856 & & \\
Competence (x) & & & & \\
Curriculum Development (y) & 905 & 11953 & 12320 & $0.689^{*}$ \\
In-service Education for staff (y) & 908 & 12072 & 12354 & $0.614^{*}$ \\
Development of leadership skills (y) & 913 & 12251 & 12402 & $0.501^{*}$ \\
Staff motivation (y) & 923 & 12433 & 12504 & $0.442^{*}$ \\
Maintenance existing facilities (y) & 907 & 11929 & 12323 & $0.706^{*}$ \\
Monitoring school activities (y) & 910 & 12180 & 12395 & $0.613^{*}$ \\
\hline
\end{tabular}

Significant at $0.05, \mathrm{df}=68$; Critical $\mathrm{r} .=0.232$

Results of analysis in Table 3 shows that, the calculated r-value for curriculum development (0.689), in-service education for staff $(0.614)$, development of leadership skills $(0.501)$, staff motivation $(0.442)$, maintenance of existing facilities $(0.706)$ and monitoring school activities $(0.613)$ were all greater than the critical $r$-value of 0.232 at 0.05 level of significance with 68 degrees of freedom. This means that, there is a significant relationship existing between principals' administrative competence and the development of effective leadership role among secondary school students in Calabar education zone of Cross river State. That is, the higher the level of principals administrative competence, the higher the development of effective leadership role in terms of curriculum development, in-service education for staff, development of leadership skills, staff motivation, maintenance of existing facilities and monitoring of school activities. By these results, the null hypothesis is rejected and the alternate upheld.

\section{Discussion}

The result of the analysis in Table 1 revealed that male principals had higher mean values in two (2) management role effectiveness for youth leadership while their female counter parts had higher mean values in four (4) management role effectiveness for youth leadership. This result supports the findings of Adadevoh (2001) and Inyang (2005) who observed that female school administrators are more enduring, tolerant, compassionate and seeking to maintain relationships. Female principals possess necessary leadership qualities together with some managerial abilities in terms of developing skills in student. The outcome of this hypothesis also corresponds with the findings of Inyang (2008) which indicated that female principals are more capable of disciplining the teachers, than their male counterparts. Supporting the above assertion is an earlier finding by Eagly and Johnson (cited by Cole, 1996) which revealed that female managers are generally more democratic, participative and relationship-oriented than male managers who are considered autocratic and directive in style, as well as, more tasks-oriented.

The findings of this study appear to contradict earlier findings by Ijaiya (1998) that female principals are too strict and unapproachable as well as autocratic. It could be that female principals are being influenced by socio-cultural factors which consider women generally as the weaker sex. Their firmness may be their own way of asserting their authority to achieve organizational goals and objectives and, women naturally are recognized for their doggedness and effectiveness in accomplishing tasks and co-operative ventures (Marshall, 1984).

The result of hypothesis two shows that both public and private school principals are not very effective in their management role effectiveness. This finding agrees with Obemeata (1984) who noted that over the years, heads of Nigerian secondary schools have been accused of various administrative lapses and offences. They are said to be inefficient and have also been accused of failing to provide direction and adequate leadership. This explains the reasons for the deteriorating standard and quality of education.

This situation has been a source of concern to the government and other stakeholders in education since the objectives of education are far from being achieved. The effect of this on the nation is better imagined. From personal interaction, a large number of principals submitted that one major challenge against effective management is population explosion in schools, which has resulted in overcrowded classrooms, ranging from 100 to 120 students 
per class in Cross River State. This situation constitutes a serious hindrance to effective classroom management and supervision. Also, poor funding creates unconducive atmosphere for learning due to lack of infrastructural facilities, together with too many conflicting rules and regulations which have not given the principals free hand in the management of schools.

With regards to hypothesis three, findings revealed that principals' administrative competence significantly relate with the development of effective leadership skills among the students. According to Ogunyemi (2010), leadership demands a number of virtues which support the individual (or a group of individuals) in moving towards attaining the vision or goals set for the organization or society. For the young members of the society, the attributes of cooperation/team spirit, honesty, self discipline, punctuality, tolerance, respect for constituted authorities and similar ones, are without doubt, instrumental to the development of leadership qualities in students. It will therefore be unrealistic to expect positive leadership skills from the Nigerian youth when the environment of their education is not conducive to the cultivation of such skills.

It can therefore be explained from the findings of this paper that due to the ineffectiveness and laxity of principals, student (youth) attention have been diverted to cultism, examination malpractice, truancy etc. This has resulted in the production of half-baked school leavers who cannot make simple correct sentences or even know their bearings in the society. How then can we achieve national transformation when these youths should be the leaders of tomorrow.

Educational planning and management must be proactive and address present and future shocks (Oguntoye \& Gobir, 2008). National transformation demands that youths, who are major stake-holders in the future, must be adequately prepared for the unfolding complexities of society. Our youths must through the kind of education they receive, be liberated mentally and physically. Ebeye (2008) confirmed that the Nigerian youth, if given the right atmosphere, training and facilities, will thrive and contribute meaningfully to the development of the Nigeria economy as the youths in developed countries. He went further to list some of the challenges the Nigerian youth is faced with to include: poor education, moral decadence in society and lack of appropriate role models. From the foregoing, the future for the Nigerian youth population does not look bright, however this can be reversed if principals who are the hubs of the educational system are constantly made aware of the needed management skills through training and re-training. These skills will go a long way to help develop leadership skills in our youth for national transformation.

\section{Conclusion}

Youth education, especially for qualitative youth leadership, is imperative for national transformation in Nigeria. Virtually all continents of the world, through established economic and, or political structures, have at different times articulated processes and programmes to achieve the all important goal of youth development which is enhanced by educational empowerment (Ebeye, 2008).

The lofty goals of secondary education cannot be achieved without proper management. The National Policy on Education believes that the success of any system of education is hinged on proper planning, efficient administration and adequate financing (FRN, 2008). This can be achieved through school principals ensuring adequate and effective planning of all educational services; providing efficient administrative and management control for the maintenance and improvement of the system; and ensuring quality control through regular and continuous supervision of instruction and other educational services. According to UNESCO (2006), education, both formal and non-formal, public awareness and training, are major processes by which human beings and societies can reach their fullest potential.

\section{Recommendations}

Based on the findings of this study, the following recommendations are made to facilitate the realization of some educational goals and objectives.

1) School principals should be paired with the opposite sex as vice-principals so as to make up for the areas of weakness of the school principal.

2) School principals need to have continuous induction courses to update their skills on managing emerging and unfamiliar management expectations.

3) Government should build more schools to decongest the large population in schools. This will create a conducive atmosphere for learning, class size will also be reduced for effective classroom management. 
4) Adequate funding by government is necessary so that principals can provide instructional materials and other facilities for effective management of schools through school community relations.

\section{References}

Adadevoh, W. (2001). Feminism, professionalism and educational leadership: An approach to capacity building in Nigerian universities. The Nigerian School Scientist, 4(2), 15-25.

Adetula, L. O. (2005). Improving the supervisory skills and competencies of inspectors of mathematics education in schools. International Journal of the Teachers Registration Council of Nigeria, 1(1), 33-40.

Akpa, G. O. (2002). The principalship: Its theory, Nigerian practice and $21^{\text {st }}$ century challenges. Jos: Ichejum Publishers.

Ayeni, A. J. (2012). Assessment of Principals' supervisory roles for quality assurance in secondary schools in Ondo State, Nigeria. World Journal of Education, 2(1), 62. http://dx.doi.org/10.5430/ wje.v2n/p62

Bass, B. M., \& Stog, D. (1990). Handbook of leadership: theory, research and managerial applications ( $3^{\text {rd }}$ Edition). New York: The Free Press.

Cole, C. A. (1996) Management, theory and practice ( ${ }^{\text {th }}$ Ed.). London: DP Publications..

Ebeye, A. P. (2008). Emerging trends in the management of youth education for sustainable development in Nigeria. In J.B. Babalola, G. O. Akpa, Hauwa and A.O.Ayeni (Eds.), Managing education for sustainable development in developing countries(pp341-349). Ibadan: NAEAP.

Enueme, C., \& Atokolo, S. S. (2008). Ensuring development in Nigeria through youths' involvement in educational management in Delta State. Journal of Educational Administration and Planning(NAEAP), 8(2), 97-108.

Ezekiel-Hart, J. (2009). Enhancing students' educational achievement by understanding and improving leadership. Annual Book of readings: Philosophy of Education Association of Nigeria, 63 - 72.

Ezenwanne, D. N. (2009). Teachers' view on principals' application of Glickman's Development Supervision model in secondary schools in Anambra State in Nigeria. Journal of Educational Administration and Planning (NAEAP), 9(2), 55-68.

Federal Republic of Nigeria (2011). The transformation agenda, 1, 59-61.

Federal Republic of Nigeria, FRN (2008). National policy on education. Lagos NERDC Press.

Harris, B. M. (1967). Supervisory behaviour in education. New Jersey, England Cliffs: Prentice Hall.

Ijaiya, U. (1998). A comparative, analysis of male and female principals' leadership qualities in selected states of Nigeria: International Journal of Educational Management(IJEM), 2(2),25-32.

Inyang, E. E. (2008). Gender and secondary education management for sustainable development in Akwa Ibom State, Nigeria. Nigerian Journal of Education Administration and Planning, 8(2), 189-200.

Lucio, W. H., \& McNeil, J. D. (1979). Supervision in thought and action. New York: McGraw Hill Book Company.

Marshall, J. (1984). Women managers - traveler in male world. London: Chichester Wiley. New Jersey, Prentice Hall.

Obemeata, J. (1984). Secondary school leadership in the Nigerian context. In S. Adesina and S. Ogunsaju (Eds.), Secondary education in Nigeria. Ille-Ife. University of Ife Press.

Oguntoye, A. O., \& Gobir, B. G. (2008). Gender and youth issues in education for sustainable development: A trend analysis of enrolments in Nigerian educational institutions. Nigerian Journal of Educational Administration and Planning (NAEAP), 8(3), 63-74.

Ogunyemi, F. T. (2010). Pre-school education and preparation of the Nigerian child for leadership. Annual Book of Reading. Philosophy of Education Association of Nigeria. 26-38.

Udoh, S. U., \& Akpa, G. O. (2007). Educational administration in Nigeria. Theory and practice (Revised Edition). Jos: Khajom Publishers.

UNESCO (2006). Education for sustainable development.

Yuks, G. (1994). Leadership in organization ( $3^{\text {rd }}$ Ed.). Englewood Cliff. 